\title{
Microbulbifer agarilyticus sp. nov. and Microbulbifer thermotolerans sp. nov., agar- degrading bacteria isolated from deep-sea sediment
}

\author{
Masayuki Miyazaki, ${ }^{1}$ Yuichi Nogi, ${ }^{1}$ Yukari Ohta, ${ }^{1}$ Yuji Hatada, ${ }^{1}$ \\ Yoshihiro Fujiwara, ${ }^{1}$ Susumu Ito $^{2}$ and Koki Horikoshi ${ }^{1}$ \\ ${ }^{1}$ Extremobiosphere Research Center, Japan Agency for Marine-Earth Science and Technology \\ (JAMSTEC), 2-15 Natsushima-cho, Yokosuka 237-0061, Japan \\ ${ }^{2}$ Creative Research Initiative Sousei (CRIS) in Hokkaido University, N21W10 Kita-ku, \\ Sapporo 001-0021, Japan
}

Yuichi Nogi

nogiy@jamstec.go.jp
The deep sea is regarded as an extreme environment with high hydrostatic pressures and predominantly low temperatures. Micro-organisms living in the deep sea presumably have developed specific characteristics that allow them to thrive in such an environment and have great biotechnological potential for the production of hydrolytic enzymes (Ferrer et al., 2005; Groudieva et al., 2004; Hung et al., 2005). Agar, which is present in the cell walls of some red algae, is composed of agarose and agaropectins. Agarases have potential applications in the food, cosmetic and medical industries for the production of oligosaccharides from agar (Kobayashi et al., 1997; Yoshizawa et al., 1995). Novel agar-degrading bacteria have been isolated from marine environments (Jean et al., 2006; Kurahashi \& Yokota, 2004; Nedashkovskaya et al., 2004). However, the agarases reported to date have not found widespread industrial applications, because of their low levels of activity, stability and productivity. We have searched for novel agarase-producing micro-organisms in several

The GenBank/EMBL/DDBJ accession numbers for the 16S rRNA gene sequences of strains JAMB $A 3^{\top}$ and $\mathrm{JAMB} A 94^{\top}$ are $\mathrm{AB} 158515$ and AB124836, respectively.

Fatty acid compositions of strains JAMB $A 3^{\top}$ and JAMB $A 94^{\top}$ and related strains are presented in a supplementary table available with the online version of this paper. deep-sea environments off Japan and have isolated novel strains of the genera Microbulbifer and Thalassomonas (Ohta et al., 2004a, b, c, 2005). These genera comprise Gram-negative, facultatively anaerobic members of the Gammaproteobacteria (Gonzalez et al., 1997; Macián et al., 2001) and include agar-degrading species that are widely distributed in nature, especially in aquatic environments such as oceans and salt marshes (Yoon et al., 2003a, b, 2004; Jean et al., 2006). In this paper, we describe the results of taxonomic studies on nine of the agar-degrading strains isolated.

Strains JAMB A3 ${ }^{\mathrm{T}}$, JAMB A7, JAMB A24, JAMB A33, JAMB A94 ${ }^{\mathrm{T}}$, JAMM 0654, JAMM 0793, JAMM 1327 and JAMM 1340 were isolated using sterilized mud samplers from various deep sites in Japan, such as a rubbish dump in Suruga Bay, a bacterial mat in Sagami Bay and a location adjacent to whale carcasses in Sagami Bay and off Kagoshima (Table 1). Microbulbifer elongatus DSM $6810^{\mathrm{T}}$ (Yoon et al., 2003b), Microbulbifer hydrolyticus DSM $11525^{\mathrm{T}}$ (Gonzalez et al., 1997), Microbulbifer salipaludis JCM $11542^{\mathrm{T}}$ (Yoon et al., 2003a), Microbulbifer maritimus JCM $12187^{\mathrm{T}}$ (Yoon et al., 2004) and Thalassomonas agarivorans JCM $13379^{\mathrm{T}}$ (Jean et al., 2006) were used as reference strains. These bacteria were maintained on marine agar 2216 (MA; Difco) plates or in marine broth 


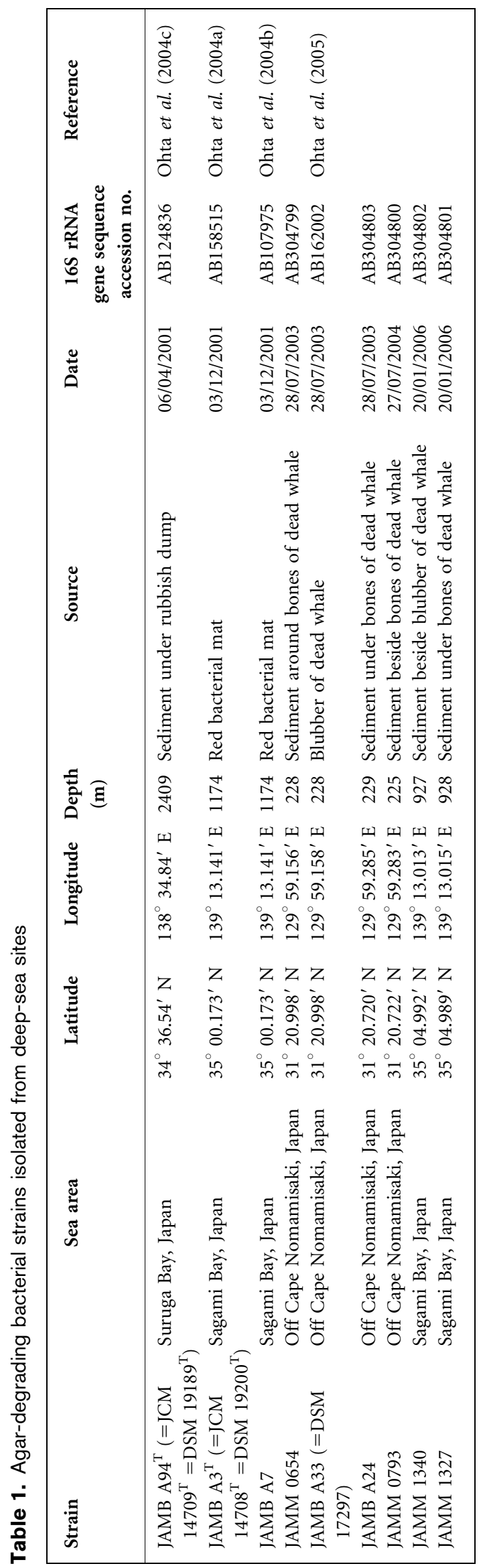

2216 (MB; Difco) were incubated aerobically for 2 or 3 days at the optimum temperature and stored at $-80{ }^{\circ} \mathrm{C}$ in $15 \%(\mathrm{v} / \mathrm{v})$ glycerol. Unless otherwise indicated, physiological tests were performed by using a slight modification (with artificial seawater: $1 \times$ artificial seawater consists of $2.75 \% \mathrm{NaCl}, \quad 0.07 \% \mathrm{KCl}, \quad 0.54 \%$ $\mathrm{MgCl}_{2} \cdot 6 \mathrm{H}_{2} \mathrm{O}, \quad 0.68 \% \quad \mathrm{MgSO}_{4} \cdot 7 \mathrm{H}_{2} \mathrm{O}, \quad 0.14 \%$ $\mathrm{CaCl}_{2} \cdot 2 \mathrm{H}_{2} \mathrm{O}, 0.02 \% \mathrm{NaHCO}_{3}$ ) of the general procedures described by Barrow \& Feltham (1993) and Baumann et al. (1972). Growth at various temperatures $\left(0-60{ }^{\circ} \mathrm{C}\right)$ in $\mathrm{MB}$ was measured. The test strains retained their viability for about 7 days at optimal temperature. Growth at various $\mathrm{NaCl}$ concentrations was examined in medium containing $0.5 \%$ peptone (Difco), $0.5 \%$ yeast extract (Difco) and $0.32 \% \mathrm{MgSO}_{4} \cdot 7 \mathrm{H}_{2} \mathrm{O}$, with $\mathrm{NaCl}$ concentrations of $0-15 \%$ $(\mathrm{w} / \mathrm{v})$. The optimal $\mathrm{pH}$ and $\mathrm{pH}$ range for growth were determined in $0.5 \%$ peptone, $0.5 \%$ yeast extract, $0.32 \%$ $\mathrm{MgSO}_{4} \cdot 7 \mathrm{H}_{2} \mathrm{O}$ and $3.0 \% \mathrm{NaCl}(\mathrm{w} / \mathrm{v})$ at $\mathrm{pH} 5.0-10.5$. Acid production from sugars was assessed using modified OF medium (Hugh \& Leifson, 1953) containing $0.5 \times$ artificial seawater, $0.1 \%\left(\mathrm{NH}_{4}\right)_{2} \mathrm{SO}_{4}, 0.1 \%$ yeast extract (Difco), $0.1 \%$ Tris, $1.4 \% \mathrm{NaCl}, 1 \%$ test sugar and $0.006 \%$ bromothymol blue ( $\mathrm{pH}$ adjusted to 7.2 at $25{ }^{\circ} \mathrm{C}$ ) with incubation at the optimum temperature. Oxidase activity was determined by spreading cell pellets on oxidase test paper (Nissui Pharmaceutical). Gelatinase, protease, amylase, lipase, chitinase and xylanase activities were detected on MA plates, using substrate concentrations of $1 \%(\mathrm{w} / \mathrm{v})$. DNase activity was assessed using DNase test agar (Difco). Hydrogen sulfide production from thiosulfate and the production of indole were assessed using sulfide indole motility agar (Nissui Pharmaceutical) stabs prepared with $0.5 \times$ artificial seawater instead of water. Susceptibility to antimicrobial substances was examined on MA using the Sensi-Disc system (Becton Dickinson). Any sign of growth inhibition after $48 \mathrm{~h}$ incubation at the optimum temperature was recorded as indicating sensitivity to the respective antimicrobial agent. The following antibiotics (Becton Dickinson) were examined: ampicillin $(10 \mu \mathrm{g})$, chloramphenicol $(30 \mu \mathrm{g})$, erythromycin $(15 \mu \mathrm{g})$, gentamicin $(10 \mu \mathrm{g})$, kanamycin $(30 \mu \mathrm{g})$, nalidixic acid $(30 \mu \mathrm{g})$, neomycin $(30 \mu \mathrm{g})$, novobiocin $(30 \mu \mathrm{g})$, penicillin (10 IU), streptomycin $(10 \mu \mathrm{g})$ and tetracycline $(30 \mu \mathrm{g})$.

Cellular fatty acids and isoprenoid quinones were analysed. The isolated strains and reference strains were cultured in $\mathrm{MB}$ at optimal temperatures. Cells were washed twice with $0.7 \% \mathrm{NaCl}$ at $4{ }^{\circ} \mathrm{C}$; this was followed by centrifugation at $8000 \mathrm{~g}$ and freeze-drying. Cellular fatty acids were analysed using a gas-liquid chromatograph/mass spectrometer and isoprenoid quinones were analysed using reversed-phase HPLC according to methods described previously (Miyazaki et al., 2006).

The DNA G + C content was determined using reversedphase HPLC (Tamaoka \& Komagata, 1984). For analysis of relatedness, DNA-DNA hybridization was carried out at $47{ }^{\circ} \mathrm{C}$ for $4 \mathrm{~h}$ and measured fluorometrically using the method of Ezaki et al. (1989). 
The 16S rRNA gene was amplified using the PCR method, with primers $27 \mathrm{~F}$ and 1492R (Lane, 1991). The PCR product was sequenced with the dideoxynucleotide chaintermination method, using a DYEnamic ET terminator (MegaBACE) reagent premix (GE Healthcare UK) and a MegaBACE 1000 DNA sequencer (GE Healthcare UK). Primers 27F, 350F, 520R, 780F, 907R, 1100F and 1492R were used in the gene-sequencing reaction. The 16S rRNA gene sequence was compared with those in the GenBank nucleotide database using online BLAST searches. Nucleotide substitution rates ( $K_{\text {nuc }}$; Kimura, 1980) were determined and a distance matrix tree was constructed using the neighbour-joining method (Saitou \& Nei, 1987) with the program CLUSTAL_X (Thompson et al., 1997). Alignment gaps and unidentified base positions were not taken into consideration in the calculations. The topology of the phylogenetic tree was evaluated by performing a bootstrap analysis based on 1000 datasets.

To investigate the taxonomic positions of the nine agardegrading strains isolated, 16S rRNA gene sequence analysis and genomic DNA-DNA hybridization studies were performed. The generally recommended and accepted criteria for delineating bacterial species state that strains with a DNA-DNA relatedness of less than $70 \%$ (as measured by hybridization) or with a 16S rRNA gene sequence dissimilarity greater than $3 \%$ are considered to belong to separate species (Wayne et al., 1987; Stackebrandt \& Goebel, 1994; Stackebrandt et al., 2002). However, bacterial strains with a difference in 16S rRNA gene sequence of less than $3 \%$ cannot be allocated to the same species without support from DNA-DNA relatedness studies. The $16 \mathrm{~S}$ rRNA gene sequence clustering demonstrated four groups that showed high levels of internal sequence similarity (99.7-100\%): (i) strains JAMB A24 and JAMB A33, (ii) strains JAMB A94 ${ }^{\mathrm{T}}$, JAMM 1327 and JAMM 1340, (iii) strains JAMB A3 ${ }^{\mathrm{T}}$, JAMM 0654 and JAMM 0793 and (iv) strain JAMB A7. In the neighbourjoining tree, the sequences form a distinct lineage, with species from the genera Microbulbifer and Thalassomonas as the closest relatives (Fig. 1). Strains JAMB A24 and JAMB A33 fall within the genus Thalassomonas. The DNA-DNA hybridization values between T. agarivorans JCM $13379^{\mathrm{T}}$ and JAMB A24 and JAMB A33 were greater than $76 \%$ (Table 2) and therefore these two strains were identified as belonging to the species T. agarivorans. Strains JAMB A3 ${ }^{\mathrm{T}}$, JAMM 0654 and JAMM 0793, strains JAMB A94 ${ }^{\mathrm{T}}$, JAMM 1327 and JAMM 1340 and strain JAMB A7 fall within the genus Microbulbifer. The results of DNA-DNA hybridization analysis indicated that the novel isolates could be divided into three groups (Table 2) matching those revealed by phylogenetic analyses, with more than $80 \%$ DNA relatedness among the strains in each group. In the $16 \mathrm{~S}$ rRNA gene sequence analysis, strains JAMB $\mathrm{A} 3^{\mathrm{T}}$, JAMM 0654 and JAMM 0793 were closely related to the type strains of $M$. salipaludis $(98.0 \%)$ and $M$. elongatus $(97.2 \%)$. The respective DNA-DNA reassociation values between strain JAMB $A 3^{\mathrm{T}}$ and these type strains were less than $35 \%$ (Table 2) and therefore strains JAMB $\mathrm{A3}^{\mathrm{T}}$, JAMM 0654 and JAMM 0793 were identified as representing a novel species. Strains JAMB A94 ${ }^{\mathrm{T}}$, JAMM 1327 and JAMM 1340 were closely related to the type strain of $M$. maritimus ( $97.1 \% 16 \mathrm{~S}$ rRNA gene sequence similarity). The DNA-DNA hybridization value between $M$. maritimus JCM $12187^{\mathrm{T}}$ and strain JAMB A94 ${ }^{\mathrm{T}}$ was less than $50 \%$ (Table 2) and therefore strains JAMB A94 ${ }^{\mathrm{T}}$, JAMM 1327 and JAMM 1340 were identified as representing a second novel species. In the $16 \mathrm{~S}$ rRNA gene sequence analysis, strain JAMB A7 was closely related to the type strains of $M$. elongatus $(98.7 \%)$ and M. salipaludis $(98.3 \%)$ and strain JAMB $A 3^{\mathrm{T}}$ (98.2\%). The DNA-DNA hybridization value of $80 \%$ (Table 2) indicated that M. elongatus DSM $6810^{\mathrm{T}}$ and strain JAMB A7 represent the same species.

Physiological and biochemical characteristics of the six strains that represent novel Microbulbifer species and the type strains of existing Microbulbifer species are shown in Table 3. A comparison of the physiological and biochemical characteristics of the two groups showed some differences with regard to each other and to the

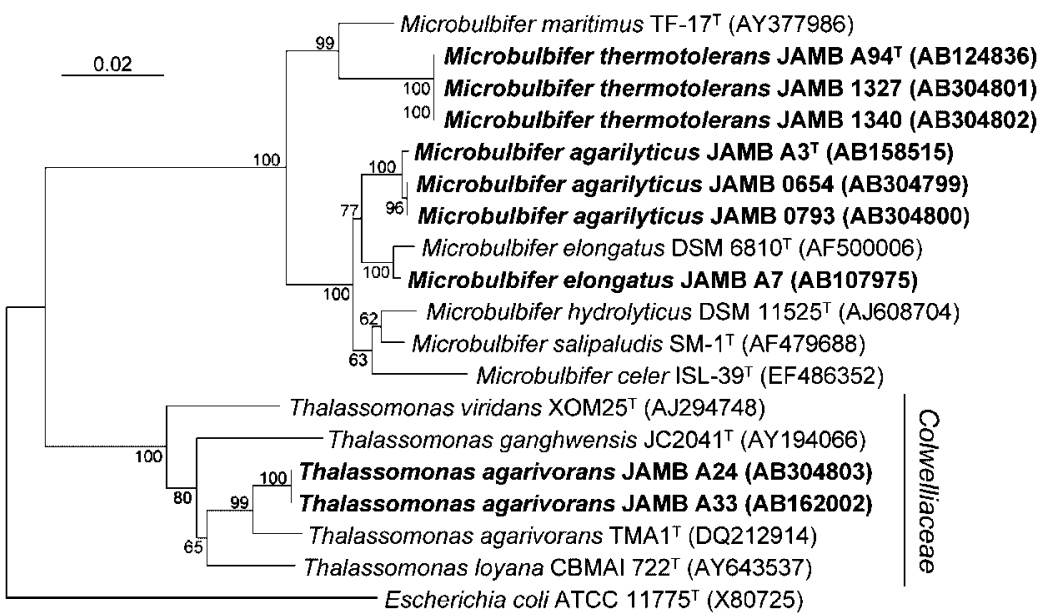

Fig. 1. Neighbour-joining phylogenetic tree, based on 16S rRNA gene sequences, showing the positions of the nine novel strains (shown in bold) with respect to members of the genera Microbulbifer and Thalassomonas. Bar, 0.02 substitutions per nucleotide position. Bootstrap percentages (based on 1000 datasets) are shown at branch points. 
Table 2. DNA-DNA reassociation between the isolated strains and closely related Microbulbifer and Thalassomonas strains

\begin{tabular}{|c|c|c|c|c|c|}
\hline \multirow[t]{2}{*}{ Strain } & \multicolumn{5}{|c|}{ DNA-DNA reassociation (\%) with labelled DNA from: } \\
\hline & 1 & 2 & 3 & 4 & 5 \\
\hline \multicolumn{6}{|l|}{ M. agarilyticus sp. nov. } \\
\hline 1. JAMB A3 ${ }^{\mathrm{T}}$ & 100 & - & - & & \\
\hline JAMM 0793 & 81 & - & - & & \\
\hline JAMM 0654 & 92 & - & - & & \\
\hline \multicolumn{6}{|l|}{ M. thermotolerans sp. nov. } \\
\hline 2. JAMB A94 ${ }^{\mathrm{T}}$ & 22 & 100 & - & & \\
\hline JAMM 1340 & - & 97 & - & & \\
\hline JAMM 1327 & - & 99 & - & & \\
\hline \multicolumn{6}{|l|}{ M. elongatus } \\
\hline 3. JAMB A7 & 17 & 20 & 100 & & \\
\hline DSM $6810^{\mathrm{T}}$ & 16 & 22 & 80 & & \\
\hline M. hydrolyticus DSM $11525^{\mathrm{T}}$ & 15 & 18 & 25 & & \\
\hline M. salipaludis JCM $11542^{\mathrm{T}}$ & 35 & 22 & 34 & & \\
\hline M. maritimus JCM $12187^{\mathrm{T}}$ & 28 & 50 & 41 & & \\
\hline \multicolumn{6}{|l|}{ T. agarivorans } \\
\hline 4. JAMB A33 & & & & 100 & - \\
\hline 5. JAMB A24 & & & & 76 & 100 \\
\hline JCM $13379^{\mathrm{T}}$ & & & & 78 & 84 \\
\hline T. ganghwensis DSM $13754^{\mathrm{T}}$ & & & & 15 & 11 \\
\hline T. viridans DSM $15355^{\mathrm{T}}$ & & & & 7 & 8 \\
\hline
\end{tabular}

Microbulbifer type strains. M. elongatus DSM $6810^{\mathrm{T}}$ and the group of strains represented by JAMB $A 3^{\mathrm{T}}$ grew at similar temperatures $\left(10-38{ }^{\circ} \mathrm{C}\right)$ but showed differing results for motility, the ONPG test, hydrolysis of aesculin, reduction of nitrate and DNA G $+\mathrm{C}$ content. The group of strains represented by JAMB $\mathrm{A} 94^{\mathrm{T}}$ grew at higher temperatures (both optimum and maximum), was motile by means of peritrichous flagella, reduced nitrate and utilized the carbohydrate substrates D-fructose, D-mannitol and trehalose.

The whole-cell fatty acid compositions of strains JAMB $\mathrm{A} 3^{\mathrm{T}}$ and JAMB $\mathrm{A} 94^{\mathrm{T}}$ and reference strains are shown in Supplementary Table S1 (available in IJSEM Online). The major fatty acids in strain JAMB $A 3^{\mathrm{T}}$ were iso- $\mathrm{C}_{15: 0}$ (isopentadecanoic acid), iso- $\mathrm{C}_{17: 1}$ (isoheptadecenoic acid) and $\mathrm{C}_{18: 1}$ (octadecenoic acid), while those for strain JAMB A-94 ${ }^{\mathrm{T}}$ were $\mathrm{C}_{16: 0}$ (hexadecanoic acid), iso- $\mathrm{C}_{15: 0}$, iso- $\mathrm{C}_{17: 1}$, $\mathrm{C}_{16: 1}$ (hexadecenoic acid) and $\mathrm{C}_{18: 1}$. For each of the isolated strains, the fatty acid profile showed low levels of similarity to those of the reference strains. For example, strain JAMB $A 3^{\mathrm{T}}$ contained large amounts of $\mathrm{C}_{18: 1}$ and strain JAMB $\mathrm{A} 94^{\mathrm{T}}$ also contained relatively large amounts of $\mathrm{C}_{16: 1}$ and $\mathrm{C}_{18: 1}$, slightly less iso- $\mathrm{C}_{15: 0}$ (isopentadecanoic acid), contained $\mathrm{C}_{10: 0} 3-\mathrm{OH}$ and did not contain $\mathrm{C}_{17: 1}$ (heptadecenoic acid).

On the basis of the phenotypic, genotypic and phylogenetic data, it is logical to conclude that six of the deep-sea, agardegrading isolates we studied are members of two novel species within the genus Microbulbifer, for which the names
Microbulbifer agarilyticus sp. nov. (type strain JAMB A3 ${ }^{\mathrm{T}}$ ) and Microbulbifer thermotolerans sp. nov. (type strain JAMB A94 ${ }^{\mathrm{T}}$ ) are proposed.

\section{Description of Microbulbifer agarilyticus sp. nov.}

Microbulbifer agarilyticus (a.gar.i.ly'ti.cus. N.L. n. agarum agar; N.L. adj. lyticus from Gr. adj. lutikos dissolving; N.L. part. adj. agarilyticus agar-dissolving).

Cells are Gram-negative, non-motile rods, $0.4-0.7 \mu \mathrm{m}$ wide and $3.5-6.5 \mu \mathrm{m}$ long. Colonies on MA are slightly irregular, smooth, cream-coloured and 2-4 $\mathrm{mm}$ in diameter after 3 days incubation at $37^{\circ} \mathrm{C}$. The optimal temperature for growth is $31-35^{\circ} \mathrm{C}$. No growth occurs at temperatures higher than $40{ }^{\circ} \mathrm{C}$. Cells are able to grow at $7 \% \mathrm{NaCl}$; optimal growth occurs at concentrations of approximately $2-3 \%$. No growth occurs in the absence of $\mathrm{NaCl}$. Growth occurs at $\mathrm{pH}$ 6.5-9.5; the optimal $\mathrm{pH}$ is 7.58.0. Facultatively anaerobic chemo-organotroph with both respiratory and fermentative types of metabolism. Catalase, cytochrome oxidase, lipase, DNase and ONPG tests are positive. Agar, xylan, chitin, casein, gelatin, starch and Tweens 40 and 80 are hydrolysed. Nitrate is reduced to nitrite. Does not hydrolyse aesculin and does not produce $\mathrm{H}_{2} \mathrm{~S}$ or indole. Acid is formed oxidatively from cellobiose, $\mathrm{D}$-glucose, maltose and xylose. No acid is produced from $\mathrm{L}-$ arabinose, D-fructose, glycerol, myo-inositol, D-lactose, Dmannitol, D-mannose, raffinose, L-rhamnose, D-sorbitol, sucrose or trehalose. Discs containing the following antibiotics cause zones of inhibition: ampicillin $(10 \mu \mathrm{g})$, 
Table 3. Differential characteristics of Microbulbifer strains

Strains: 1, JAMB A3 ${ }^{\mathrm{T}}$, JAMM 0654 and JAMM 0793 (M. agarilyticus sp. nov.); 2, strains JAMB A94 ${ }^{\mathrm{T}}$, JAMM 1327 and JAMM 1340 (M.

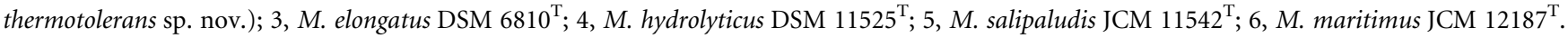
All strains show the following properties: they are Gram-negative rods that do not form spores, they test positive for catalase, oxidase and hydrolysis of casein, DNA, gelatin, starch, Tween 40 and Tween 80, the major isoprenoid quinone type is Q-8, acid is produced from cellobiose, D-glucose and maltose, hydrogen sulfide and indole are not produced, nitrite is not reduced to nitrogen and acid is not produced from glycerol, D-lactose, myoinositol, D-mannose, D-raffinose, L-rhamnose, D-sorbitol or sucrose.

\begin{tabular}{|c|c|c|c|c|c|c|}
\hline Characteristic & 1 & 2 & 3 & 4 & 5 & 6 \\
\hline Cell morphology & Rods & Cocci or rods & Cocci or rods & Rods & Rods & Rods \\
\hline Colony colour & Cream & Brown & Yellowish brown & Cream & Greyish yellow & Yellowish brown \\
\hline Motility & - & + & + & - & - & - \\
\hline \multicolumn{7}{|l|}{ Temperature for growth $\left({ }^{\circ} \mathrm{C}\right)$} \\
\hline Optimum & $31-35$ & $43-49$ & 34 & 37 & 37 & 37 \\
\hline Maximum & $35-38$ & $52-54$ & 38 & 41 & 45 & 48 \\
\hline Growth at $10 \% \mathrm{NaCl}$ & - & - & - & - & + & + \\
\hline Agarase & + & + & + & - & + & - \\
\hline ONPG test & + & - & - & - & + & - \\
\hline Lipase & + & + & + & - & + & - \\
\hline Xylanase & + & + & + & + & + & - \\
\hline Chitinase & + & + & + & + & - & - \\
\hline \multicolumn{7}{|l|}{ Hydrolysis of: } \\
\hline Aesculin & - & + & + & + & - & - \\
\hline Tween 20 & $+(1 / 3)$ & + & - & + & - & + \\
\hline Nitrate reduction & + & + & - & - & + & + \\
\hline \multicolumn{7}{|l|}{ Acid from: } \\
\hline L-Arabinose & - & - & - & + & - & - \\
\hline D-Fructose & - & + & - & - & - & - \\
\hline D-Galactose & $+(2 / 3)$ & - & - & - & - & - \\
\hline D-Mannitol & - & + & - & - & - & - \\
\hline Trehalose & - & + & - & - & - & + \\
\hline Xylose & + & + & + & + & - & - \\
\hline DNA G $+C$ content $(\mathrm{mol} \%)$ & $55.2-55.3$ & $56.0-56.2$ & 57.1 & 57.5 & 58.1 & 60.2 \\
\hline
\end{tabular}

chloramphenicol $(30 \mu \mathrm{g})$ and nalidixic acid $(30 \mu \mathrm{g})$. Discs containing gentamicin $(10 \mu \mathrm{g})$, streptomycin $(10 \mu \mathrm{g})$ or tetracycline $(30 \mu \mathrm{g})$ do not cause any growth inhibition. The DNA G $+\mathrm{C}$ content of the type strain is $55.2 \mathrm{~mol} \%$. The major isoprenoid quinone is Q-8. The predominant cellular fatty acids are iso- $\mathrm{C}_{15: 0}$, iso- $\mathrm{C}_{17: 1}$ and $\mathrm{C}_{18: 1}$.

The type strain, JAMB $\mathrm{A}^{\mathrm{T}}\left(=\mathrm{JCM} \quad 14708^{\mathrm{T}}=\mathrm{DSM}\right.$ $19200^{\mathrm{T}}$ ), was isolated from a deep-sea bacterial mat in Sagami Bay, Japan.

\section{Description of Microbulbifer thermotolerans sp. nov.}

Microbulbifer thermotolerans (ther.mo.to'le.rans. Gr. n. thermê heat; L. pres. part. tolerans tolerating; N.L. part. adj. thermotolerans heat-tolerating).

Cells are 0.4-0.6 $\mu \mathrm{m}$ wide and 2.5-5.5 $\mu \mathrm{m}$ long; both rods and coccoid cells occur. Cells are Gram-negative and motile by means of peritrichous flagella. Colonies on MA are slightly irregular, smooth, brown-coloured and 2$4 \mathrm{~mm}$ in diameter after 3 days incubation at $40{ }^{\circ} \mathrm{C}$. The optimal temperature for growth is $43-49{ }^{\circ} \mathrm{C}$; no growth occurs at temperatures higher than $55{ }^{\circ} \mathrm{C}$. Cells are able to grow with $\mathrm{NaCl}$ at $7 \%$; optimal growth occurs at concentrations of approximately $1-2 \%$. No growth occurs in the absence of $\mathrm{NaCl}$. Growth occurs at $\mathrm{pH} 5.5-9.0$; the optimal $\mathrm{pH}$ is $6.5-7.5$. Facultatively anaerobic chemoorganotroph with both respiratory and fermentative types of metabolism. Catalase, cytochrome oxidase, lipase and DNase tests are positive. Agar, xylan, chitin, casein, gelatin, starch, aesculin and Tweens 20, 40 and 80 are hydrolysed. Nitrate is reduced to nitrite. Does not produce $\mathrm{H}_{2} \mathrm{~S}$ or indole. Acid is formed oxidatively from cellobiose, Dfructose, D-glucose, maltose, D-mannitol, trehalose and xylose. No acid is produced from L-arabinose, D-galactose, glycerol, myo-inositol, D-lactose, D-mannose, raffinose, Lrhamnose, D-sorbitol or sucrose. Discs containing the following antibiotics cause zones of inhibition: ampicillin $(10 \mu \mathrm{g})$, chloramphenicol $(30 \mu \mathrm{g})$, gentamicin $(10 \mu \mathrm{g})$, kanamycin $(30 \mu \mathrm{g})$, neomycin $(30 \mu \mathrm{g})$, penicillin (10 IU) and streptomycin $(10 \mu \mathrm{g})$. The DNA G $+\mathrm{C}$ content of the type strain is $56.2 \mathrm{~mol} \%$. The major isoprenoid quinone is Q-8. The predominant cellular fatty acids are iso- $C_{16: 0}$, iso- $\mathrm{C}_{15: 0}$, iso- $\mathrm{C}_{17: 1}, \mathrm{C}_{16: 1}$ and $\mathrm{C}_{18: 1}$. 
The type strain, JAMB A94 ${ }^{\mathrm{T}}\left(=\mathrm{JCM} 14709^{\mathrm{T}}=\mathrm{DSM}\right.$ $\left.19189^{\mathrm{T}}\right)$, was isolated from deep-sea sediment from Suruga Bay, Japan.

\section{References}

Barrow, G. I. \& Feltham, R. K. A. (1993). Cowan and Steel's Manual for the Identification of Medical Bacteria, 3rd edn. New York: Cambridge University Press.

Baumann, L., Baumann, P., Mandel, M. \& Allen, R. D. (1972). Taxonomy of aerobic marine eubacteria. J Bacteriol 110, 402-429.

Ezaki, T., Hashimoto, Y. \& Yabuuchi, E. (1989). Fluorometric deoxyribonucleic acid-deoxyribonucleic acid hybridization in microdilution wells as an alternative to membrane filter hybridization in which radioisotopes are used to determine genetic relatedness among bacterial strains. Int J Syst Bacteriol 39, 224-229.

Ferrer, M., Golyshina, O. V., Chernikova, T. N., Khachane, A. N., Martins Dos Santos, V. A., Yakimov, M. M., Timmis, K. N. \& Golyshin, P. N. (2005). Microbial enzymes mined from the Urania deep-sea hypersaline anoxic basin. Chem Biol 12, 895-904.

Gonzalez, J. M., Mayer, F., Moran, M. A., Hodson, R. E. \& Whitman, W. B. (1997). Microbulbifer hydrolyticus gen. nov., sp. nov., and Marinobacterium georgiense gen. nov., sp. nov., two marine bacteria from a lignin-rich pulp mill waste enrichment community. Int J Syst Bacteriol 47, 369-376.

Groudieva, T., Kambourova, M., Yusef, H., Royter, M., Grote, R., Trinks, H. \& Antranikian, G. (2004). Diversity and cold-active hydrolytic enzymes of culturable bacteria associated with Arctic sea ice, Spitzbergen. Extremophiles 8, 475-488.

Hugh, R. \& Leifson, E. (1953). The taxonomic significance of fermentative versus oxidative metabolism of carbohydrates by various Gram negative bacteria. J Bacteriol 66, 22-26.

Hung, V. S., Hatada, Y., Goda, S., Lu, J., Hidaka, Y., Li, Z., Akita, M., Ohta, Y., Watanabe, K. \& other authors (2005). $\alpha$-Glucosidase from a strain of deep-sea Geobacillus: a potential enzyme for the biosynthesis of complex carbohydrates. Appl Microbiol Biotechnol 68, 757-765.

Jean, W. D., Shieh, W. Y. \& Liu, T. Y. (2006). Thalassomonas agarivorans sp. nov., a marine agarolytic bacterium isolated from shallow coastal water of An-Ping Harbour, Taiwan, and emended description of the genus Thalassomonas. Int J Syst Evol Microbiol 56, 1245-1250.

Kimura, M. (1980). A simple method for estimating evolutionary rates of base substitutions through comparative studies of nucleotide sequences. J Mol Evol 16, 111-120.

Kobayashi, R., Takisada, M., Suzuki, T., Kirimura, K. \& Usami, S. (1997). Neoagarobiose as a novel moisturizer with whitening effect. Biosci Biotechnol Biochem 61, 162-163.

Kurahashi, M. \& Yokota, A. (2004). Agarivorans albus gen. nov., sp. nov., a $\gamma$-proteobacterium isolated from marine animals. Int $J$ Syst Evol Microbiol 54, 693-697.

Lane, D. J. (1991). 16S/23S rRNA sequencing. In Nucleic Acid Techniques in Bacterial Systematics, pp. 115-175. Edited by E. Stackebrandt \& M. Goodfellow. Chichester: Wiley.

Macián, M. C., Ludwig, W., Schleifer, K. H., Garay, E. \& Pujalte, M. J. (2001). Thalassomonas viridans gen. nov., sp. nov., a novel marine $\gamma$ proteobacterium. Int J Syst Evol Microbiol 51, 1283-1289.

Miyazaki, M., Nogi, Y., Usami, R. \& Horikoshi, K. (2006). Shewanella surugensis sp. nov., Shewanella kaireitica sp. nov. and Shewanella abyssi sp. nov., isolated from deep-sea sediments of Suruga Bay, Japan. Int J Syst Evol Microbiol 56, 1607-1613.

Nedashkovskaya, O. I., Suzuki, M., Vancanneyt, M., Cleenwerck, I., Lysenko, A. M., Mikhailov, V. V. \& Swings, J. (2004). Zobellia amurskyensis sp. nov., Zobellia laminariae sp. nov. and Zobellia russellii sp. nov., novel marine bacteria of the family Flavobacteriaceae. Int J Syst Evol Microbiol 54, 1643-1648.

Ohta, Y., Hatada, Y., Nogi, Y., Li, Z., Zhang, H.-M., Ito, S. \& Horikoshi, K. (2004a). Thermostable $\beta$-agarase from a deep-sea Microbulbifer isolate. J Appl Glycosci 51, 203-210.

Ohta, Y., Hatada, Y., Nogi, Y., Miyazaki, M., Li, Z., Akita, M., Hidaka, Y., Goda, S., Ito, S. \& Horikoshi, K. (2004b). Enzymatic properties and nucleotide and amino acid sequences of a thermostable $\beta$-agarase from a novel species of deep-sea Microbulbifer. Appl Microbiol Biotechnol 64, 505-514.

Ohta, Y., Nogi, Y., Miyazaki, M., Li, Z., Hatada, Y., Ito, S. \& Horikoshi, K. (2004c). Enzymatic properties and nucleotide and amino acid sequences of a thermostable $\beta$-agarase from the novel marine isolate, JAMB-A94. Biosci Biotechnol Biochem 68, 1073-1081.

Ohta, Y., Hatada, Y., Miyazaki, M., Nogi, Y., Ito, S. \& Horikoshi, K. (2005). Purification and characterization of a novel alpha-agarase from a Thalassomonas sp. Curr Microbiol 50, 212-216.

Saitou, N. \& Nei, M. (1987). The neighbor-joining method: a new method for reconstructing phylogenetic trees. Mol Biol Evol 4, 406-425.

Stackebrandt, E. \& Goebel, B. M. (1994). Taxonomic note: a place for DNA-DNA reassociation and $16 \mathrm{~S}$ rRNA sequence analysis in the present species definition in bacteriology. Int J Syst Bacteriol 44, 846-849.

Stackebrandt, E., Frederiksen, W., Garrity, G. M., Grimont, P. A. D., Kämpfer, P., Maiden, M. C. J., Nesme, X., Rosselló-Mora, R., Swings, J. $\&$ other authors (2002). Report of the ad hoc committee for the reevaluation of the species definition in bacteriology. Int J Syst Evol Microbiol 52, 1043-1047.

Tamaoka, J. \& Komagata, K. (1984). Determination of DNA base composition by reversed-phase high-performance liquid chromatography. FEMS Microbiol Lett 25, 125-128.

Thompson, J. D., Gibson, T. J., Plewniak, F., Jeanmougin, F. \& Higgins, D. G. (1997). The CLUSTAL_X Windows interface: flexible strategies for multiple sequence alignment aided by quality analysis tools. Nucleic Acids Res 25, 4876-4882.

Wayne, L. G., Brenner, D. J., Colwell, R. R., Grimont, P. A. D., Kandler, O., Krichevsky, M. I., Moore, L. H., Moore, W. E. C., Murray, R. G. E. \& other authors (1987). International Committee on Systematic Bacteriology. Report of the ad hoc committee on reconciliation of approaches to bacterial systematics. Int J Syst Bacteriol 37, 463-464.

Yoon, J. H., Kim, I. G., Shin, D. Y., Kang, K. H. \& Park, Y. H. (2003a). Microbulbifer salipaludis sp. nov., a moderate halophile isolated from a Korean salt marsh. Int J Syst Evol Microbiol 53, 53-57.

Yoon, J. H., Kim, H., Kang, K. H., Oh, T. K. \& Park, Y. H. (2003b). Transfer of Pseudomonas elongata Humm 1946 to the genus Microbulbifer as Microbulbifer elongatus comb. nov. Int J Syst Evol Microbiol 53, 1357-1361.

Yoon, J. H., Kim, I. G., Oh, T. K. \& Park, Y. H. (2004). Microbulbifer maritimus sp. nov., isolated from an intertidal sediment from the Yellow Sea, Korea. Int J Syst Evol Microbiol 54, 1111-1116.

Yoshizawa, Y., Ametani, A., Tsunehiro, J., Nomura, K., Itoh, M., Fukui, F. \& Kaminogawa, S. (1995). Macrophage stimulation activity of the polysaccharide fraction from a marine alga (Porphyra yezoensis): structure-function relationships and improved solubility. Biosci Biotechnol Biochem 59, 1933-1937. 